\title{
ОЦЕНКА ПРОДУКТИВНОСТИ И ПИТАТЕЛЬНОСТИ СМЕШАННЫХ ПОСЕВОВ СОИ С ОДНОЛЕТНИМИ ЗЛАКОВЫМИ КУЛЬТУРАМИ В УСЛОВИЯХ ПРИМОРСКОГО КРАЯ
}

\section{A.A. Avramenko, T.V. Naumova, O.V. Pavlova}

\section{THE ESTIMATION OF PRODUCTIVITY AND NUTRITION OF MIXED SOY SEEDS WITH ANNUAL CEREAL CROPS IN THE CONDITIONS OF PRIMORSK REGION}

Авраменко Анастасия Александровна асп., ст. преп. каф. землеустройства Приморской государственной сельскохозяйственной академии, Приморский край, г. Уссурийск.

E-mail: pgsa@rambler.ru

Наумова Татьяна Владимировна - канд. С.-х. наук, доц. каф. землеустройства Приморской государственной сельскохозяйственной академии, Приморский край, г. Уссурийск.

E-mail: pgsa@rambler.ru

Павлова Ольга Владимировна - канд. с.-х. наук, доц. каф. агротехнологий Приморской государственной сельскохозяйственной академии, Приморский край, г. Уссурийск.

E-mail: pgsa@rambler.ru

Приведены результаты двулетних исследований использования сои в смешанных посевах кормовых культур, рекомендованньх для воздельвания в условиях Приморского края. Исследования проводились в 2017-2018 г2. на полях ФГБОУ ВО «Приморская ГСХА». Почва участка лугово-бурая оподзоленная, тяжелая по механическому составу. Метеорологические условия в различной степени соответствовали биологическим потребностям сои. Высокое содержание влаги в период прорастания, бутонизации, иветения и завязьвания бобов положительно повлияло на развитие растений. Цель исследований - провести сравнительную оценку продуктивности и питательности смешанных посевов сои с однолетними злаковыми культурами, обеспечивающими стабильное повышение урожайности и качества кормов. Опьты включал copm cou Приморская 86, однолетние злаковые культуры: пайза, суданская трава, кукуруза, сорго. Оченивались посевы по фенологическим наблюдениям, химическому составу, динамике роста растений, урожайности, продуктивности и питательности зеленой и сухой массы. Мини-
Avramenko Anastasia Alexandrovna - PostGraduate Student, Senior Lecturer, Chair of Land Management, Primorsk State Agricultural Academy, Primorsk Region, Ussuriisk.

E-mail: pgsa@rambler.ru

Naumova Tatyana Vladimirovna - Cand. Agr. Sci., Assoc. Prof., Chair of Land Management, Primorsk State Agricultural Academy, Primorsk Region, Ussuriisk.

E-mail: pgsa@rambler.ru

Pavlova Olga Vladimirovna - Cand. Agr. Sci., Assoc. Prof., Chair of Agrotechnologies, Primorsk State Agricultural Academy, Primorsk Region, Ussuriisk.

E-mail: pgsa@rambler.ru

мальный период вегетации отмечен у варианта сои Приморская 86. По высоте растений выделился посев сои Приморская 86+ку-куруза, ОН превзошел стандарт сои Приморская 86 в фразе иветения на 9,1 см, а в фразе бобообразованияна 7,77 см соответственно. По продуктивности и питательности выделился посев сои Приморская 86+пайза. В условиях муссонного климата Приморского края из изученных вариантов по остальным показателям выделились смешанные посевы сои Приморская 86 с пайзой и сои Приморская 86 с кукурузой, которые превзошли контроль.

Ключевые слова: соя, смешанные посевы, урожайность, зеленая масса, сухое вещество, продуктивность, питательность.

The results of two-year studies of the use of soy in mixed crops of forage crops recommended for cultivation in the conditions of the Primorsk Region were presented. The studies were conducted in 2017-2018 in the fields of FSBEl "Primorsk State Agricultural Academy". The soil of the site was 
meadow-brown podzolized, heavy in mechanical composition. Meteorological conditions to varying degrees corresponded to biological needs of soy. High moisture content during the period of germination, budding, flowering and tying of beans positively affected the development of plants. The purpose of the research was to carry out a comparative assessment of the productivity and nutritional value of mixed soybean crops with annual cereals that provide stable increase in yield and feed quality. The experiment included the Primorskaya 86 soybean variety, annual cereals: paiza, sudana grass, maize, sorghum. The crops were evaluated basing on phenological observation, chemical composition, plant growth dynamics, yield, productivity and nutriousness of green and dry mass. The minimum vegetation period was marked for Primorskaya 86 soy variant. According to the height of plants, the seeding of soy Primorskaya 86+corn was distinguished, it exceeded the standard of soy Primorskaya 86 in flowering phase by $9.1 \mathrm{~cm}$, and in the bean formation phase by $7.77 \mathrm{~cm}$, respectively. In terms of productivity and nutrition, Primorskaya $86+$ payza soybean crop was distinguished. In the conditions of the monsoon climate of Primorsk Region, from the studied options for the rest of the indicators, mixed crops of the soy Primorskaya 86 with payza and soy Primorskaya 86 with corn were distinguished, which exceeded the control.

Keywords: soy, mixed crops, productivity, green mass, dry matter, productivity, nutriousness.

Введение. Соя - одна из важнейших зернобобовых и масличных культур мирового земледелия, так как в семенах содержится 33,7 \% белка, 18 \% жира и 6,3 \% углеводов [1]. Благодаря своему уникальному биохимическому составу соя является культурой многофункционального использования. Помимо прямого применения как продукта питания для населения соя является хорошей кормовой культурой [2].

Кроме зерна в качестве корма используются все части этого растения: зеленые листья и стебли, солома, зерно и его отходы в качестве концентрированного корма (мука, шрот, жмых, молоко, экструдированная соя). Из сои получают хорошо поедаемый животными силос [3, 4].
Зеленая масса сои высокопитательная: в 100 кг такого корма содержится 21-22 кормовые единицы и 3,5-4,2 кг переваримого протеина. Ее как в чистом виде, так и в смеси с другими культурами, богатыми сахарами (кукурузой, пайзой, овсом, суданской травой и другими), можно применять для подкормки скота в летний период и при заготовке силоса и сенажа при насыщении травостоя соей в количестве 30-33 \% [5].

Цель исследований. Сравнительная оценка продуктивности и питательности смешанных посевов сои с однолетними злаковыми культурами, обеспечивающими стабильное повышение урожайности и качества кормов.

Задачи исследований: определить продуктивность смешанных посевов с возможностью использования их в качестве зеленого корма, сенажа и монокорма. Поэтому вышеперечисленные смешанные посевы убирали в фазах цветения и бобообразования.

Методы исследований. Исследования по смешанным посевам сои с однолетними культурами в условиях Приморского края проводились на полях ФГБОУ ВО «Приморская ГСХА». Почва участка лугово-бурая оподзоленная, тяжелая по механическому составу. Гидролитическая кислотность - 4,10 мэкв/100 г почвы, $\mathrm{pH}$ солевой вытяжки - 4,9. Содержание подвижного фоссрора низкое - 3,1 мг, обменного калия 14,3 мг/100г почвы, азота легкогидролизируемого - 7,3 мг/100 г почвы, гумуса $-2,75 \%$.

В опыт включены следующие культуры: соя сорт Приморская 86, пайза, суданская трава, кукуруза, сорго. Посев проводился в мае, рядовым способом. Опыты и исследования выполнялись в соответствии с методическими указаниями (Доспехов Б.А., 1989; ВНИИ кормов им. В.Р. Вильямса, 1987).

Результаты и их обсуждение. Фенологические фазы - фазы вегетации развития растений, обусловленные образованием новых органов или частей растений, фиксируемые по морфологическим изменениям. Фенологические наблюдения представлены в таблице 1.

Минимальный период вегетации отмечен у сои - сорт Приморская 86 - 111 дней. У оставшихся вариантов, включенных в испытание, не наблюдалось существенных различий. 
Продолжительность фенологических периодов смешанных посевов (среднее за 2017-2018 гг.), дней

\begin{tabular}{|c|c|c|c|c|c|c|c|c|}
\hline \multirow[b]{3}{*}{ Сорт } & \multicolumn{8}{|c|}{ Период } \\
\hline & \multirow[b]{2}{*}{ 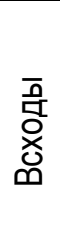 } & \multirow[b]{2}{*}{ 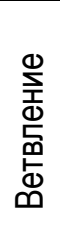 } & \multirow[b]{2}{*}{ 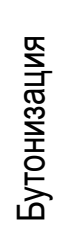 } & \multirow[b]{2}{*}{ 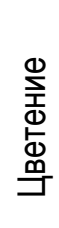 } & \multicolumn{3}{|c|}{ Бобооразование } & \multirow[b]{2}{*}{$\begin{array}{c}\text { Период } \\
\text { вегетации }\end{array}$} \\
\hline & & & & & 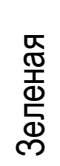 & 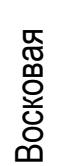 & 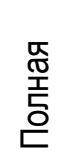 & \\
\hline Приморская 86+ пайза & 18 & 10 & 33 & 15 & 14 & 3 & 26 & 119 \\
\hline Приморская 86+суд. трава & 17 & 10 & 34 & 14 & 16 & 3 & 22 & 116 \\
\hline Приморская 86+кукуруза & 16 & 11 & 35 & 15 & 15 & 2 & 21 & 115 \\
\hline Приморская 86+сорго & 16 & 10 & 34 & 14 & 16 & 3 & 21 & 114 \\
\hline Приморская 86 (контроль) & 14 & 9 & 32 & 15 & 15 & 3 & 23 & 111 \\
\hline
\end{tabular}

Таблица 2

Динамика роста растений (среднее за 2017-2018 гг.)

\begin{tabular}{|c|c|c|c|c|c|}
\hline Фаза роста & $\begin{array}{c}\text { Приморская } \\
\text { 86+пайза }\end{array}$ & $\begin{array}{c}\text { Приморская } \\
\text { 86+суд. тра- } \\
\text { ва } \\
\end{array}$ & $\begin{array}{l}\text { Приморская } \\
\text { 86+кукуруза }\end{array}$ & $\begin{array}{c}\text { Приморская } \\
\text { 86+сорго }\end{array}$ & $\begin{array}{c}\text { Приморская } \\
86 \text { (контроль) }\end{array}$ \\
\hline Цветение & 25,4 & 20,0 & 28,4 & 27,5 & 19,3 \\
\hline Бобообразование & 52,79 & 39,69 & 64,51 & 61,32 & 56,74 \\
\hline
\end{tabular}

По высоте растений выделился посев сои Приморская 86+кукуруза, он превзошел контроль Приморская 86 в фразе цветения на 9,1 см, а в фазе бобообразования на 7,77 см соответственно.

Математическая обработка показала, что урожайность зеленой и сухой массы находится в прямой корреляционной зависимости от высоты растений. Так, в фразу цветения коэфффициент корреляции равен 0,48 , а в фазу бобообразования $-r=0,63$.

Таким образом, чем больше высота растений, тем выше урожайность зеленой и сухой массы.

Учет накопления зеленой и сухой массы проводился в фазы цветения и бобообразования. Из изучаемых смешанных посевов сои за 20172018 гг. в данные фазы развития растений наибольшая урожайность зеленой и сухой массы была у вариантов Приморская 86, Приморская 86+кукуруза. Высокая урожайность зеленой и сухой массы была отмечена у посева Приморская 86+кукуруза. По урожайности зеленой массы он превосходил контроль Приморская 86 на 0,27 т/га, а сухой массы на 1,33 т/га соответственно (табл. 3).

Для оценки питательности был проведен химический анализ зеленой массы (табл. 4).

По содержанию сырого протеина в фазе цветения выделился вариант сои Приморская 86+сорго, который превзошел контроль на 1,65 \%. Также по данному показателю выделились посевы сои Приморская 86 с пайзой, суданской травой и кукурузой, которые превзошли контроль в данной фазе от 1,0 до 1,1 \% соответственно. 
Урожайность зеленой массы и абсолютно сухого вещества в смешанных посевах сои

Таблица 3 (среднее за 2017-2018 гг.), т/га

\begin{tabular}{|l|c|c|c|c|}
\hline \multirow{2}{*}{\multicolumn{1}{|c|}{ Сорт }} & \multicolumn{2}{|c|}{ Цветение } & \multicolumn{2}{c|}{ Бобообразование } \\
\cline { 2 - 5 } & $\begin{array}{c}\text { Зеленая } \\
\text { масса }\end{array}$ & $\begin{array}{c}\text { Абсолютно сухое } \\
\text { вещество }\end{array}$ & $\begin{array}{c}\text { Зеленая } \\
\text { масса }\end{array}$ & $\begin{array}{c}\text { Абсолютно сухое } \\
\text { вещество }\end{array}$ \\
\hline Приморская 86+ пайза & 14,80 & 2,70 & 34,36 & 7,15 \\
\hline Приморская 86+суд. трава & 15,22 & 2,87 & 31,50 & 6,58 \\
\hline Приморская 86+кукуруза & 16,20 & 3,16 & 39,54 & 8,50 \\
\hline Приморская 86+сорго & 16,33 & 3,82 & 32,71 & 6,24 \\
\hline Приморская 86 (контроль) & 20,70 & 3,52 & 39,27 & 7,17 \\
\hline НСР $_{0,05}$ & 0,3 & 0,1 & 0,7 & 0,2 \\
\hline
\end{tabular}

Таблица 4

Содержание питательных веществ в зеленой массе смешанных посевов сои (среднее за 2017-2018 гг.), \% на абсолютно сухое вещество

\begin{tabular}{|c|c|c|c|c|c|c|}
\hline Сорт & $\begin{array}{c}\text { Сырой } \\
\text { жир }\end{array}$ & $\begin{array}{c}\text { Сырой } \\
\text { протеин }\end{array}$ & $\begin{array}{c}\text { Сырая } \\
\text { клетчатка }\end{array}$ & $\begin{array}{c}\text { Сырая } \\
\text { зола }\end{array}$ & Калий & Фосфpop \\
\hline \multicolumn{7}{|c|}{ Цветение } \\
\hline Приморская 86+ пайза & 2,74 & 14,65 & 14,15 & 9,52 & 2,18 & 0,36 \\
\hline Приморская 86+суд. трава & 2,63 & 14,60 & 14,10 & 9,18 & 2,33 & 0,50 \\
\hline Приморская 86+кукуруза & 2,12 & 14,55 & 12,25 & 9,72 & 2,32 & 0,40 \\
\hline Приморская 86+сорго & 3,23 & 15,20 & 13,90 & 9,81 & 2,42 & 0,34 \\
\hline Приморская 86 (контроль) & 2,65 & 13,55 & 12,80 & 10,04 & 2,40 & 0,33 \\
\hline \multicolumn{7}{|c|}{ Бобообразование } \\
\hline Приморская 86+ пайза & 3,71 & 8,70 & 15,55 & 4,99 & 3,54 & 0,40 \\
\hline Приморская 86+суд. трава & 3,86 & 9,75 & 18,20 & 5,72 & 2,85 & 0,38 \\
\hline Приморская 86+кукуруза & 3,82 & 9,15 & 18,95 & 6,35 & 2,60 & 0,37 \\
\hline Приморская 86+сорго & 3,50 & 9,05 & 19,15 & 5,43 & 3,11 & 0,40 \\
\hline Приморская 86 (контроль) & 3,42 & 8,90 & 18,85 & 5,55 & 3,20 & 0,37 \\
\hline
\end{tabular}

В фазе бобообразования по содержанию сырого протеина выделился посев сои Приморская 86+суданская трава, который превзошел контроль на 0,85\%. Минимальное содержание протеина отмечалось у варианта сои Приморская 86+пайза.

Одним из важнейших показателей в ценности кормов является их продуктивность и питательность (табл. 5).

По продуктивности и питательности выделились посевы сои Приморская 86 с пайзой и суданской травой.
Наибольшее содержание кормовых единиц и переваримого протеина с 1 кг сухого вещества в фазе цветения получен у смешанного посева сои Приморская 86+сорго, который превзошел контроль на 0,53 г.

В фазе бобообразования максимальное содержание кормовых единиц и переваримого протеина с 1 кг сухого вещества получен у посева Приморская 86+кукуруза, он превзошел контроль на 8,5 г. 
Таблица 5

Продуктивность и питательность смешанных посевов сои в условиях Приморского края (среднее за 2017-2018 гг.)

\begin{tabular}{|c|c|c|c|c|c|}
\hline \multirow[b]{2}{*}{ Сорт } & \multicolumn{2}{|c|}{ Сбор с 1 га, т } & \multicolumn{2}{|c|}{ Содержание в 1 кг сухого в-ва } & \multirow{2}{*}{$\begin{array}{c}\text { Обеспеченность, } \\
1 \text { корм.ед. пере- } \\
\text { варимым протеи- } \\
\text { ном }\end{array}$} \\
\hline & $\begin{array}{c}\text { кормовых } \\
\text { единиц }\end{array}$ & $\begin{array}{c}\text { переваримого } \\
\text { протеина }\end{array}$ & $\begin{array}{c}\text { кормовых } \\
\text { единиц }\end{array}$ & $\begin{array}{c}\text { переваримого } \\
\text { протеина, г }\end{array}$ & \\
\hline \multicolumn{6}{|c|}{ Фаза цветения } \\
\hline $\begin{array}{c}\text { Приморская 86+ } \\
\text { пайза }\end{array}$ & 1,82 & 0,12 & 4,90 & 151,00 & 37,32 \\
\hline $\begin{array}{c}\text { Приморская 86+ } \\
\text { суд. Трава }\end{array}$ & 1,82 & 0,12 & 5,21 & 153,00 & 32,45 \\
\hline $\begin{array}{c}\text { Приморская 86+ } \\
\text { кукуруза }\end{array}$ & 1,82 & 0,12 & 5,73 & 146,00 & 26,72 \\
\hline $\begin{array}{c}\text { Приморская 86+ } \\
\text { сорго }\end{array}$ & 1,82 & 0,13 & 6,93 & 155,00 & 23,55 \\
\hline $\begin{array}{c}\text { Приморская } 86 \\
\text { (контроль) }\end{array}$ & 1,82 & 0,11 & 6,40 & 154,00 & 33,96 \\
\hline \multicolumn{6}{|c|}{ Фаза бобообразования } \\
\hline $\begin{array}{c}\text { Приморская 86+ } \\
\text { пайза } \\
\end{array}$ & 1,82 & 0,07 & 12,98 & 161,00 & 13,17 \\
\hline $\begin{array}{c}\text { Приморская 86+ } \\
\text { суд. Трава } \\
\end{array}$ & 1,81 & 0,08 & 11,94 & 168,00 & 15,93 \\
\hline $\begin{array}{c}\text { Приморская 86+ } \\
\text { кукуруза }\end{array}$ & 1,81 & 0,07 & 15,41 & 179,00 & 12,66 \\
\hline $\begin{array}{c}\text { Приморская 86+ } \\
\text { сорго } \\
\end{array}$ & 1,81 & 0,07 & 11,32 & 163,50 & 15,30 \\
\hline $\begin{array}{c}\text { Приморская } 86 \\
\text { (контроль) }\end{array}$ & 1,81 & 0,07 & 13,00 & 170,50 & 14,71 \\
\hline
\end{tabular}

На основе полученных данных можно сделать выводы, что в Приморском крае из изученных смешанных посевов сои по фенологическим наблюдениям, урожайности зеленой массы и абсолютно сухого вещества, химическому составу, продуктивности и питательности за 20172018 гг. выделился вариант сои Приморская 86+пайза. Также высокие показатели были получены в посевах сои Приморская 86 с суданской травой и кукурузой, которые превзошли контроль сои Приморская 86.

\section{Литература}

1. Актуальные вопросы земледелия, возделывания и переработки сельскохозяйственных культур // Развитие аграрного производства в Азиатско-Тихоокеанском регионе: мат-лы Междунар. науч.-практ. конф. в рамках российско-японского форума / отв. ред. С.В. Иншаков; ФГБОУ ВО Приморская ГСХА. Уссурийск, 2016. 132 с.

2. Роль аграрной науки в развитии лесного и сельского хозяйства Дальнего Востока: мат-лы Всерос. науч.-практ. конф., посвящ. 60-летию со дня образования ФГБОУ ВО Приморская ГСХА (ноябрь 2017 г.): Ч. І / ФГБОУ ВО Приморская ГСХА; отв. ред. С.В. Иншаков. Уссурийск, 2017. 178 с.

3. Мерзляков А.И., Вольнюк А.Д. Результаты выращивания сои в Тюменской области // Сельскохозяйственные науки и агропромышленный комплекс на рубеже веков. 2015. № 10. C. 111-114.

4. Современные тенденции селекции и агротехнологии сои: коллективная монография / A.В. Редкокашина [и др.]; под ред. С.В. Ин- 
шакова; коллектив авторов. Уссурийск: ФГБОУ ВО Приморская ГСХА, 2016. 167 с.

5. Соя на Дальнем Востоке / А.П. Ващенко, Н.В. Мудрик, П.П. Фисенко [и др.]; Россельхозакадемия, ДВ РНЦ, Примор. НИИСХ. Владивосток: Дальнаука, 2010. 435 с.

\section{Literatura}

1. Aktual'nye voprosy zemledelija, vozdelyvanija i pererabotki sel'skohozjajstvennyh kul'tur // Razvitie agrarnogo proizvodstva $\vee$ AziatskoTihookeanskom regione: mat-ly Mezhdunar. nauch.-prakt. konf. $\mathrm{v}$ ramkah rossijskojaponskogo foruma / otv. red. S.V. Inshakov; FGBOU VO Primorskaja GSHA. Ussurijsk, 2016. $132 \mathrm{~s}$.

2. Rol' agrarnoj nauki $v$ razvitii lesnogo i sel'skogo hozjajstva Dal'nego Vostoka: mat-ly
Vseros. nauch.-prakt. konf., posvjashh. 60letiju so dnja obrazovanija FGBOU VO Primorskaja GSHA (nojabr' 2017 g.): Ch. I / FGBOU VO Primorskaja GSHA; otv. red. S.V. Inshakov. Ussurijsk, 2017. $178 \mathrm{~s}$.

3. Merzljakov A.I., Vol'njuk A.D. Rezul'taty vyrashhivanija soi v Tjumenskoj oblasti // Sel'skohozjajstvennye nauki agropromyshlennyj kompleks na rubezhe vekov. 2015. № 10. S. 111-114.

4. Sovremennye tendencii selekcii i agrotehnologii soi: kollektivnaja monografija / A.V. Redkokashina [i dr.]; pod red. S.V. Inshakova; kollektiv avtorov. Ussurijsk: FGBOU VO Primorskaja GSHA, 2016. $167 \mathrm{~s}$.

5. Soja na Dal'nem Vostoke / A.P. Vashhenko, N.V. Mudrik, P.P. Fisenko [i dr.]; Rossel'hozakademija, DV RNC, Primor. NIISH. Vladivostok: Dal'nauka, 2010. 435 s. 